\title{
Vineyard protection with rain-shelter: relationships between radiometric properties of plastic covers and table grape quality
}

\author{
Laura de Palma ${ }^{1}$, Patrizio Limosani ${ }^{1}$, Iva Marasovic ${ }^{1}$, Sandra Pati $^{1}$, Giuliano Vox ${ }^{2}$, Evelia Scettini $^{2}$, and Vittorino \\ Novello ${ }^{3}$ \\ ${ }^{1}$ University of Foggia, Department of Science of Agriculture, Food and Environment, Via Napoli 25, 71122 Foggia, Italy \\ ${ }^{2}$ University of Bari, Department of Agricultural and Environmental Science, Via Amendola 165/A, 70126 Bari, Italy \\ ${ }^{3}$ University of Turin, Department of Agricultural, Forest and Food Sciences, Largo Braccini 2, 10095 Grugliasco (TO), Italy
}

\begin{abstract}
The rise of unpredictable, heavy rainfalls increases incidence of diseases, berry rot, berry cracking, and enhance the need for rain shelters. The influence of the type of rain shelter on microclimate and grape quality is still little explored. The aim of this trial was to investigate the radiometric properties of a new type of cover, its effect on vineyard microclimate and on table grape quality, as compared with a reference cover, during a vintage with unusually abundant precipitation for Southern Italy. The new cover was characterized by lower transmissivity to IRshort radiation, and by a very higher transmissivity to UV radiation. It showed a tendency to decrease air temperature by $1{ }^{\circ} \mathrm{C}$, increase RH by $2-3 \%$, reduce VPD, and improve vine water status with respect to the reference. At harvest, grapes covered with the new sheet had higher TSS concentration, TSS / TA ratio, total skin polyphenol and flavonoids content, and berry skin resistance to rupture. Those berries, moreover, increased the level of volatile compounds such as linalool, typical of 'Italia' muscat aroma, and terpineol.
\end{abstract}

\section{Introduction}

The rise in unpredictability of heavy rainfalls enhances incidence of diseases, berry rot, berry cracking, and consequent use of pesticides. Rain shelters can be used to mitigate these effects.

Covering table grape vineyards with plastic sheets, in order to protect grapes and to allow a harvest delay up-to 30-90 days, has been done in Italy since the mid-1960s, and was improved as 'late covering technique' [1]. Since the sheets are usually set-up at veraison, when berries become more sensitive to rot, and they are rolled out only above the foliage, these covers were originally considered only as a mechanical protection from rain. However, plastic sheet coverings inevitably filter the incoming solar radiation and alter its radiometric traits, modifying the microenvironment and influencing vine ecophysiological function and grape quality $[2,3,4]$. Nevertheless, the influence of the type of plastic sheet on microclimate of 'late covered vineyards' and on their grape quality is still little explored. The aim of the present trial was to investigate the features of a new type of rain shelter, and to compare it with a reference cover, by analysing the sheet radiometric properties and their effects on the canopy microenvironment and on the quality attributes of table grapes during a vintage with unusually abundant precipitation for Southern Italy.

\section{Materials and methods}

The trial was carried out on a 1-hectare commercial vineyard of Laporta farm, located in Trinitapoli (BT province, Apulia region, Italy, $\left.41^{\circ} 18^{\prime} \mathrm{N}, 16^{\circ} 00 \mathrm{E}\right)$. It was established in 2007 grafting cv. Italia onto $140 \mathrm{Ru}$ rootstock planted 2.4 x $2.4 \mathrm{~m}$ apart on clay-loam soil. Vines were trained to overhead tendone trellis (Puglia type), pruned to 4 canes with 10 buds/cane, and protected with white hail net during the growing cycle.

The year 2014 was characterized by unusually heavy rainfalls during grape ripening (Fig. 1), with $209 \mathrm{~mm}$ between July and mid-October (equal to $38 \%$ of the average annual regional rainfall, namely $550 \mathrm{~mm}$ ). In particular, in the $1^{\text {st }}$ and in the $3^{\text {rd }}$ ten-day periods of September, and in the $1^{\text {st }}$ ten-day period of October, there were 54, 29 and $52 \mathrm{~mm}$ of rains, respectively. In that year, some vineyard rows were covered with a new type of plastic sheet consisting of a polyethylene fabric, $200 \mu \mathrm{m}$ thick, provided by Beaulieu Technical Textile (Belgium). This treatment was labelled as NEW. The other rows were covered with a commercial polyethylene film $80 \mu \mathrm{m}$ thick, very popular in the region, as a reference; this treatment was labelled as REF. Both cover types were transparent to solar radiation and equipped with additives including antistatic, anti-drop and UV stabilizers. They were set up on August $10^{\text {th }}$ (veraison), over the hail net, in alternate

\footnotetext{
Corresponding author: laura.depalma@unifg.it
} 
groups of 4 adjacent rows. Three replicates of 10 representative vines/replicate were considered. Before the cover set-up, in order to estimate the influence of the hail net on the amount of photosynhetically active radiation (PAR) available for vines, the photosynthetic photon flux (PPF) filtering though the net over canopy was measured at 15 vine positions/treatment (solar bars AccuPar LP80, Decagon), and compared with that available in open air. The number of shoots/vine and of bunches/shoot was assessed. Farm viticultural practices were applied uniformly, either before or after covering, including cluster selection (1.5 bunch/cane), leaf thinning to improve light penetration through the foliage, sub-irrigation and fertigation.

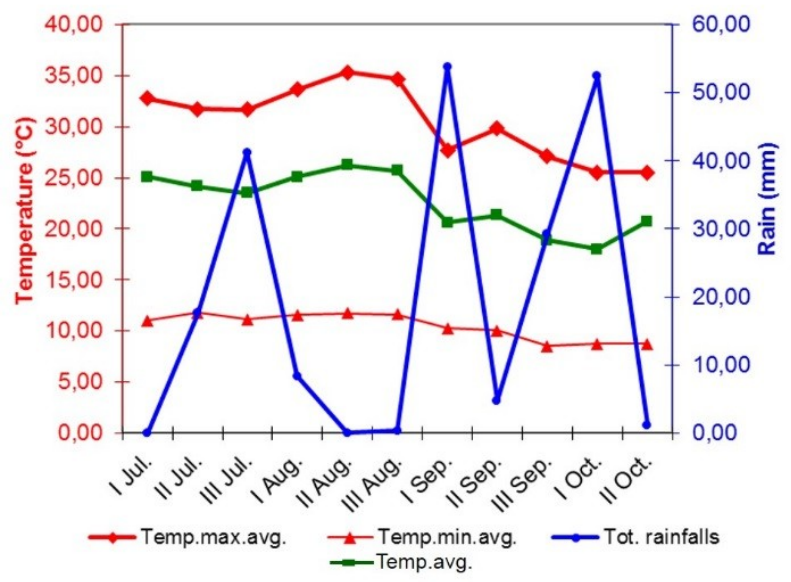

Fig. 1. Thermo-hydrometric diagram for cv. Italia ripening period (2014 year).

Cover radiometric properties were analyzed according to Vox et al. [5]. In the solar wavelength range (200-2500 $\mathrm{nm})$, direct transmissivity was measured (10 nm steps) using a double beam UVVIS-NIR spectrophotometer (Lambda 950 Perkin Elmer) with perpendicular ray incidence, while for total transmissivity an integrating sphere (diam. $60 \mathrm{~mm}$ ) was used; diffuse transmissivity was calculated as the difference. Transmissivity coefficients, as weighted average values, were calculated [6]. Within the solar radiation, the following wavelength ranges were also considered: photosynthetically active radiation (PAR, 400-700 $\mathrm{nm}$ ), short infrared radiation $\left(\mathrm{IR}_{\mathrm{s}}, 700-2500 \mathrm{~nm}\right.$ ); ultraviolet radiation (UV 220-320 nm), UVB (280-320 nm), and UVA (320-380).

In two consecutive typical days of August $\left(19^{\text {th }}\right.$ and $\left.20^{\text {th }}\right)$ and of September $\left(16^{\text {th }}\right.$ and $\left.17^{\text {th }}\right)$, at mid-morning (from $11: 30$ to $12.30 \mathrm{hrs}$.), microclimatic parameters were measured in open air ( $2 \mathrm{~m}$ above the ground) and under the covers. PPF was taken on horizontal plain; under covers, it was measured at 3 levels: over canopy, at ground, and at the fruiting zone pointing down the solar bar sensors to intercept light reflection from soil to grapes. Air temperature and relative humidity $\left(\mathrm{T}_{\mathrm{air}}, \mathrm{RH}\right.$, thermo-hygrometers HD $8501 \mathrm{H}$, Delta Ohm) were taken over canopy ( $2.45 \mathrm{~m}$ above the soil) and at bunch level (1.80 $\mathrm{m}$ above the soil). The air vapour pressure deficit $\left(V D_{a i r}\right)$ was calculated. The vine water status was assessed as stem water potential ( $\Psi_{\text {stem }}, 2$ leaves/vine). In 2 days, measurements were taken at each vine position.

From August $19^{\text {th }}$ to harvest, at intervals of 8-10 days, berries were sampled from several bunch portions in order to monitor their quality attributes. On 50 berries/replicate, the following parameters were assessed: berry weight, skin colour (CIE L*a*b*, chroma meter Konica Minolta CR400), juice total soluble solids concentration (TSS, refractometer VM-7 Atago), juice titratable acidity (TA, as tartaric acid) by neutralization with $\mathrm{NaOH} 0.1 \mathrm{~N}$ (Titralyzer Laboratories Dujardin-Salleron T11-107). On 10 berries/replicate, peeled skins were extracted in $\mathrm{EtOH}: \mathrm{H}_{2} \mathrm{O}: \mathrm{HCl}$ (70:30:1, $\mathrm{pH} 1)$ for $24 \mathrm{hrs}$. to evaluate: index of total polyphenol content (TP) and of flavonoid content (TF). For TP, 0.1 $\mathrm{mL}$, added with $1 \mathrm{~mL}$ of Folin reagent and $4 \mathrm{~mL} \mathrm{Na}_{2} \mathrm{CO}_{3}$ $(10 \%)$, was brought up to $20 \mathrm{~mL}$ volume with distilled $\mathrm{H}_{2} \mathrm{O}$, and read at $750 \mathrm{~nm}$ using a spectrophotometer (Shimadzou UV-1700). For TF, extracts were 50 times diluted with $\mathrm{EtOHCl}$, and read from 230 to $400 \mathrm{~nm}$. Calculations were done [7]. On the skin extracts, antioxidant activity (AA) was assessed by $\mathrm{ABTS}^{+}$ method [8]. ABTS ${ }^{+}$solution was diluted in ethanol (1:88) whose absorbance, at $30^{\circ} \mathrm{C}$ and $734 \mathrm{~nm}$, is $\sim 0.70$ ( \pm 0.02 ), against ethanol as blank. $200 \mu \mathrm{L}$ of diluted sample were added to $2 \mathrm{~mL}$ of chromogen into a $10 \mathrm{~mm}$ $\mathrm{pl}$ cuvette; after $15 \mathrm{~min}$, the absorbance at $734 \mathrm{~nm}$ was read. Calculation of percentage inhibition: Inhib. $(\%)=(1-$ $\left.\mathrm{Abs}_{\mathrm{s}} / \mathrm{Abs}_{\mathrm{b}}\right) * 100$ ( $\mathrm{s}=$ sample, $\mathrm{b}=$ blank). The equivalent concentration $(\mu \mathrm{mol} / \mathrm{L}$ Trolox $\mu \mathrm{M})$ was obtained by replacing the inhib.(\%) in Trolox standard curve.

Grape aromas were analyzed by headspace solid phase microextraction, by using an $85 \mu \mathrm{m}$ carboxen /polydimethylsiloxane fibre (Supelco). Grapes were defrosted at $5{ }^{\circ} \mathrm{C}$, pedicels and seeds were removed. 100 $\mathrm{g}$ of berries, $2 \mathrm{~g}$ of $\mathrm{CaCl}_{2}, 20 \mathrm{~g}$ of $\mathrm{NaCl}$ and $100 \mu \mathrm{L}$ of internal standard solution $(100 \mu \mathrm{g} / \mathrm{g}$ 2-methylpentanol methanolic solution) were homogenized. For each measurement, $8 \mathrm{~g}$ of puree was put into a $15 \mathrm{~mL}$ capped SPME vial. After $20 \mathrm{~min}$ of sample stirring at $40{ }^{\circ} \mathrm{C}$, the fibre was exposed to the capped vial headspace for 30 min. Then it was inserted into the gas chromatograph (GG) in splitless mode (temperature $250{ }^{\circ} \mathrm{C}$ ) for 4 min to allow the volatile desorption. Volatile determination was done by a $6890 \mathrm{~N}$ GS equipped with a 5975C mass spectrometer (Agilent Technologies). Analytes were separated on a DB-WAX capillary column $(60 \mathrm{~m} \times 250$ $\mu \mathrm{m} \times 0.25 \mu \mathrm{m})$ with the following program: $40{ }^{\circ} \mathrm{C}$ for 4 min, $40-180{ }^{\circ} \mathrm{C}$ at $3{ }^{\circ} \mathrm{C} / \mathrm{min}$ (total run $51 \mathrm{~min}$ ). The transfer line temperature was $280{ }^{\circ} \mathrm{C}$. Mass detector conditions were electronic impact mode at $70 \mathrm{eV}$, source temperature $230{ }^{\circ} \mathrm{C}$, scanning rate $2.88 \mathrm{scan} / \mathrm{s}$ and mass scanning range $m / z$ 30-400. The carrier gas was helium at $1 \mathrm{~mL} / \mathrm{min}$. Identification of volatile compounds was achieved comparing their mass spectra with reference spectra contained in a library (NIST 02) of reference data (matching probability $P>80$ ) and comparing their retention times and mass spectra with those obtained by standard injections of pure compounds. Compounds were quantified as $\mu \mathrm{g} 2$-methylpentanol equivalent/g. 
Data collected from replicates were statistically processed by one-way ANOVA, at 95 percent probability level, in order to assess the effects exerted by the two covers. Data are presented as average of the replicates \pm standard error.

\section{Results and discussion}

The analysis of radiometric coefficients pointed out that the two covers had quite similar transmittance to photosynthetically active radiation (PAR), while, as for the IRs wavelength range, the NEW cover had lower transmittance to the direct component $(-22 \%)$, namely the most powerful in heating. Nonetheless, the NEW cover showed a much higher transmittance to Ultraviolet (UV) radiation, that modulates the biosynthesis of secondary metabolites essential for berry quality and healthy properties, such as phenols and flavours [9]. As for the UVB wavelength range, that is the most active, the increase was $300 \%$ for the direct component, and $544 \%$ for the diffuse component, that has more chance to penetrate throughout canopy gaps.

Table 1. Radiometric coefficients of the covers.

\begin{tabular}{|c|c|c|c|c|c|c|}
\hline \multirow{3}{*}{ 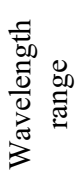 } & \multicolumn{6}{|c|}{ Transmissivity (\%) } \\
\hline & \multicolumn{2}{|c|}{ Total } & \multicolumn{2}{|c|}{ Direct } & \multicolumn{2}{|c|}{ Diffuse } \\
\hline & NEW & REF & NEW & REF & NEW & REF \\
\hline Solar & 72 & 76 & 43 & 50 & 29 & 26 \\
\hline PAR & 72 & 74 & 38 & 36 & 34 & 38 \\
\hline IRs & 73 & 79 & 49 & 63 & 24 & 16 \\
\hline UV & 74 & 35 & 27 & 16 & 47 & 19 \\
\hline UVB & 81 & 15 & 24 & 6 & 58 & 9 \\
\hline UVA & 74 & 35 & 28 & 16 & 47 & 19 \\
\hline
\end{tabular}

The comparison between PPF available in open air and under the hail net before the plastic sheet covering was rolled out, showed that hail net allowed $90 \pm 4 \%$ of PAR to pass through.

Microclimatic measurements at mid-morning of midAugust summer days showed the following values: PPF $1600 \pm 6 \mu \mathrm{mol} / \mathrm{m}^{2} / \mathrm{s}, \mathrm{T}_{\text {air }} 30.7 \pm 0.3{ }^{\circ} \mathrm{C}$, UR $43.4 \pm 0.5 \%$, $\mathrm{VPD}_{\text {air }} 2.4 \pm 0.6 \mathrm{kPa}$. Under covers (Tab. 2), PPF intercepted over the canopy was $54 \%$ of that available in open air: this amount was compatible with that expected considering the PAR transmissivity of the covers (Tab. 1) and the amount of PAR that can filter though the white net. PPF intercepted at the ground (about 90-100 $\mu \mathrm{mol} / \mathrm{m}^{2} / \mathrm{s}$ ) was high for a tendone trained canopy, and showed that leaf thinning was effective in improving light penetration. PAR reflected at bunch level was about $40 \%$ of that reaching the soil. Differences between treatments were small and not statistically significant.

Air over the canopy (Tab. 2) was hot in both NEW and REF treatments $\left(44-45^{\circ} \mathrm{C}\right)$, with RH about $49-51 \%$, and high $\mathrm{VPD}_{\text {air }}(4.5-5.0 \mathrm{kPa})$, while, at bunch level, $\mathrm{T}_{\text {air }}(30-$ $\left.31{ }^{\circ} \mathrm{C}\right), \mathrm{RH}(43-40 \%)$ and $\mathrm{VDP}_{\text {air }}(2-3 \mathrm{kPa})$ were close to open air values, and $\Psi_{\text {stem }}(-0.7$ to $-0.8 \mathrm{MPa})$ indicated a medium vine water status [10]. At bunch level, differences between covers were statistically significant. On the whole, the NEW cover, respect to the REF one, showed a tendency to decrease air temperature by $1{ }^{\circ} \mathrm{C}$, increase RH by 2-3 percent points, reduce VPD by $10 \%$, and improve vine water status by $7 \%$. The tendency for lower air temperature can be related to the lower transmissivity of the NEW cover to IRs wavelength range. In September, micro-environmental values were more moderate. At mid-morning, open air microclimate showed: PPF $1525 \pm 9 \mu \mathrm{mol} / \mathrm{m}^{2} / \mathrm{s}, \mathrm{T}_{\text {air }} 23.7 \pm 0.1^{\circ} \mathrm{C}$, UR $60.4 \pm 0.6 \%$, VPD $1.1 \pm 0.2 \mathrm{kPa}$. Under covers, tendencies found in August were overall confirmed (Tab. 2). Nonetheless, with respect to August, PPF at the ground increased to about $130-115 \mu \mathrm{mol} / \mathrm{m}^{2} / \mathrm{s}$ thanks to the last leaf thinning, but the amount reflected from soil decreased to $35 \%$ due to more green weeds; check measurements taken on green-weed strips showed $20 \%$ of PAR reflection. $\Psi$ stem about $-0.6 \mathrm{MPa}$ indicated a better vine water status.

Table 2. Mid-morning microclimate of typical summer days, in 'late covered' vineyard cv. Italia, according to the type of

plastic cover.

\begin{tabular}{|c|c|c|c|c|}
\hline \multirow{2}{*}{ Parameter } & \multicolumn{2}{|c|}{ Mid-August } & \multicolumn{2}{|c|}{ Mid-September } \\
\hline & NEW & REF & NEW & REF \\
\hline $\begin{array}{c}\text { PPF over } \\
\text { canopy } \\
\left(\mu \mathrm{mol} / \mathrm{m}^{2} / \mathrm{s}\right)\end{array}$ & $\begin{array}{l}877 \mathrm{a} \\
\pm 13\end{array}$ & $\begin{array}{l}876 \mathrm{a} \\
\pm 11\end{array}$ & $\begin{array}{l}783 \mathrm{a} \\
\pm 24\end{array}$ & $\begin{array}{l}799 a \\
\pm 13\end{array}$ \\
\hline $\begin{array}{l}\text { PPF at ground } \\
\left(\mu \mathrm{mol} / \mathrm{m}^{2} / \mathrm{s}\right)\end{array}$ & $\begin{array}{l}99 \mathrm{a} \\
\pm 6\end{array}$ & $\begin{array}{l}91 \mathrm{a} \\
\pm 6\end{array}$ & $\begin{array}{l}128 \mathrm{a} \\
\pm 14\end{array}$ & $\begin{array}{l}115 \mathrm{a} \\
\pm 3\end{array}$ \\
\hline $\begin{array}{l}\text { PPF reflected } \\
\text { from ground to } \\
\text { bunch } \\
\left(\mu \mathrm{mol} / \mathrm{m}^{2} / \mathrm{s}\right)\end{array}$ & $\begin{array}{l}39.3 \mathrm{a} \\
\pm 4\end{array}$ & $\begin{array}{l}36.0 \mathrm{a} \\
\pm 3\end{array}$ & $\begin{array}{l}44.6 \mathrm{a} \\
\pm 5\end{array}$ & $\begin{array}{c}36.5 \mathrm{a} \\
\pm 4\end{array}$ \\
\hline $\begin{array}{c}\mathrm{T}_{\text {air }} \text { over canopy } \\
\left({ }^{\circ} \mathrm{C}\right)\end{array}$ & $\begin{array}{l}44.4 \mathrm{a} \\
\pm 0.9\end{array}$ & $\begin{array}{l}45.4 \mathrm{a} \\
\pm 0.8\end{array}$ & $\begin{array}{l}33.2 \mathrm{a} \\
\pm 0.7\end{array}$ & $\begin{array}{c}34.2 \mathrm{a} \\
\pm 0.8\end{array}$ \\
\hline $\begin{array}{c}\text { UR over canopy } \\
(\%)\end{array}$ & $\begin{array}{l}51.0 \mathrm{a} \\
\pm 3.5\end{array}$ & $\begin{array}{l}48.8 \mathrm{~b} \\
\pm 2.7\end{array}$ & $\begin{array}{l}88.6 \\
\pm 2.5\end{array}$ & $\begin{array}{l}84.8 \\
\pm 2.4\end{array}$ \\
\hline $\begin{array}{c}\mathrm{VPD}_{\text {air }} \text { over } \\
\text { canopy } \\
(\mathrm{kPa})\end{array}$ & $\begin{array}{c}4.5 \\
\pm 0.3\end{array}$ & $\begin{array}{c}5.0 \\
\pm 0.5\end{array}$ & $\begin{array}{l}0.6 \mathrm{~b} \\
\pm 0.1\end{array}$ & $\begin{array}{l}0.9 \mathrm{a} \\
\pm 0.1\end{array}$ \\
\hline $\begin{array}{c}\mathrm{T}_{\text {air }} \text { bunch level } \\
\left({ }^{\circ} \mathrm{C}\right)\end{array}$ & $\begin{array}{c}30.3 \mathrm{~b} \\
\pm 0.1\end{array}$ & $\begin{array}{l}31.0 \mathrm{a} \\
\pm 0.2\end{array}$ & $\begin{array}{c}22.6 \mathrm{a} \\
\pm 0.3\end{array}$ & $\begin{array}{c}23.2 \mathrm{a} \\
\pm 0.2\end{array}$ \\
\hline $\begin{array}{c}\text { UR bunch level } \\
(\%)\end{array}$ & $\begin{array}{c}43.5 \mathrm{a} \\
\pm 0.4\end{array}$ & $\begin{array}{c}40.1 \mathrm{~b} \\
0.4\end{array}$ & $\begin{array}{l}74.7 \mathrm{a} \\
\pm 0.5\end{array}$ & $\begin{array}{l}69.7 \mathrm{~b} \\
\pm 1.5 \\
\end{array}$ \\
\hline $\begin{array}{c}\mathrm{VPD}_{\text {air }} \text { bunch } \\
\text { level } \\
(\mathrm{kPa})\end{array}$ & $\begin{array}{l}2.4 \mathrm{a} \\
\pm 0.1\end{array}$ & $\begin{array}{l}2.7 \mathrm{~b} \\
\pm 0.2\end{array}$ & $\begin{array}{l}0.7 \mathrm{~b} \\
\pm 0.1\end{array}$ & $\begin{array}{l}0.9 \mathrm{a} \\
\pm 0.1\end{array}$ \\
\hline $\begin{array}{c}\Psi_{\text {stem }} \\
(\mathrm{MPa})\end{array}$ & $\begin{array}{c}-0.72 \mathrm{a} \\
\pm 0.3 \\
\end{array}$ & $\begin{array}{l}-0.77 \mathrm{~b} \\
\pm 0.3 \\
\end{array}$ & $\begin{array}{c}-0.59 a \\
\pm 0.3\end{array}$ & $\begin{array}{c}-0.64 \mathrm{~b} \\
\pm 0.3\end{array}$ \\
\hline
\end{tabular}

Within row, for each date, values followed by different letters were statistically different at ANOVA F test $(\mathrm{p}=0.05)$.

According to measurements of vegetative-reproductive parameters, vines of the NEW and REF treatments had very similar number of shoots (35-36) and bunches/shoot (1.7-1.6).

'Italia' berry weight after veraison increased at the same rate in both treatments until the end of September $(\sim 10$ $\mathrm{g}$ ), when it was quite constant for one week, and finally slightly decreased (Fig. 2a), showing that, at that point of berry evolution, transpiration overcame the water influx. In fact, the rains of that period, different than those 
occurring in the $1^{\text {st }}$ ten-day period of September, had a very low influence on parameters related to berry growth and to metabolite concentration. The more humid microclimate of NEW cover slowed this last process: at harvest, the berry was 3\% heavier than the REF one. However, despite this result, the final NEW bunch weight $(642.8 \pm 45.6 \mathrm{~g})$ was lower by $4 \%$ than that of REF grape $(669.9 \pm 60.2 \mathrm{~g})$, since the former had fewer berries $(68.4 \pm 6.2)$ than the latter $(74.0 \pm 6.1)$. The harvest operations include the removal of rotten berries from bunches: the more humid microenvironment of the NEW cover seems to have slightly increased the mass of berries needed to be removed.

Juice of grapes under the NEW cover tended to increase TSS concentration and lower TA (Fig. 2b). In this treatment 'Italia' grape reached the minimum maturity requirement suggested by OIV Resolution Viti 1/2008 (TSS / TA ratio $\geq 20$ ) on $29^{\text {th }}$ August (Fig. 2c); under REF cover, this threshold was reached within the next 10 days.
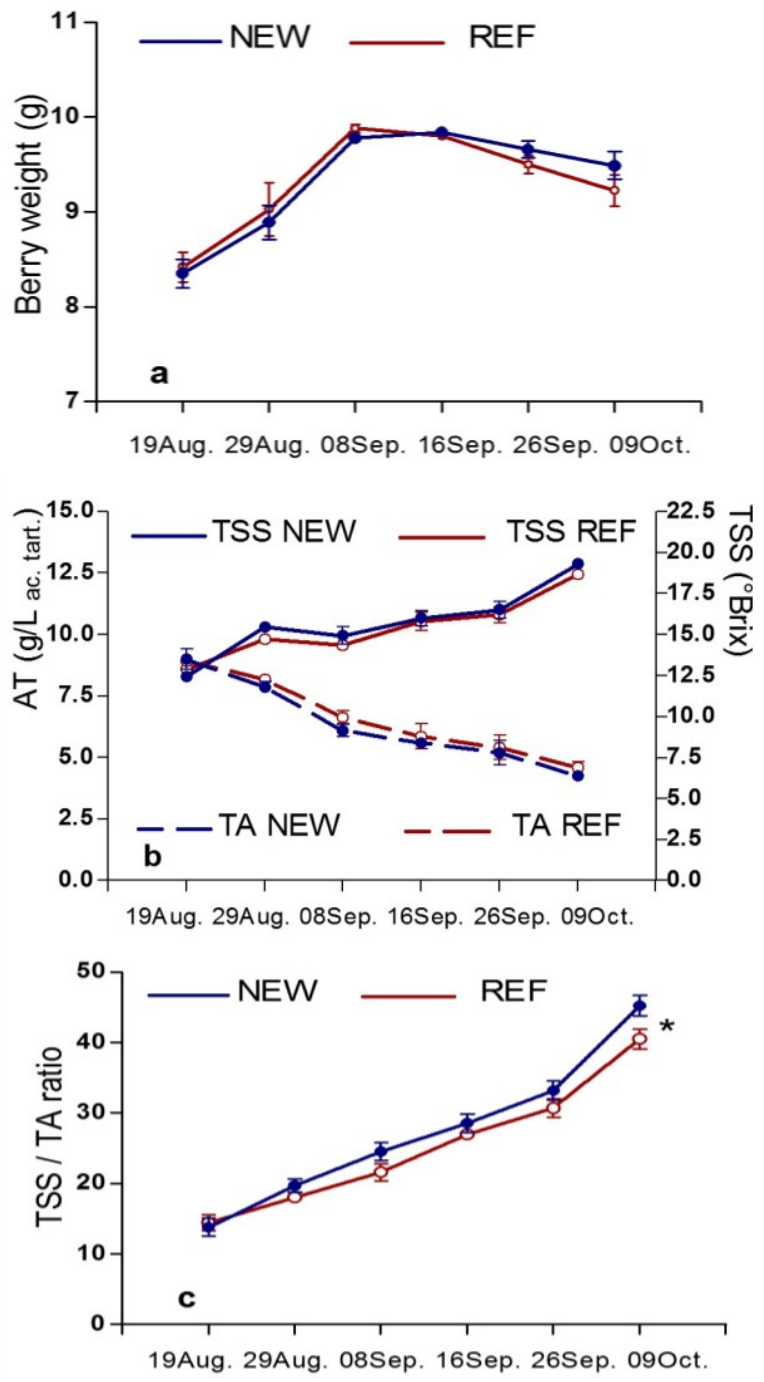

Fig. 2. Evolution of berry weight (a), total soluble solids and titratable acidity (b), TSS / TA ratio (c), in 'late covered' grape $\mathrm{cv}$. Italia, according to the type of plastic cover (bars represent standard errors; * indicates sampling date where ANOVA F test was significant at $\mathrm{p}=0.05$ ).
The cover did not influence berry skin colour. At harvest, colour coordinates were: $L^{*} 29.2 \pm 0.9$, a*$3.2 \pm 0.1, b^{*} 8.3 \pm 0.1$ for the NEW berry, $L^{*} 38.6 \pm 1, a^{*}-$ $3.1 \pm 0.1, b^{*} 7.9 \pm 0.6$ for the REF berry. However, the treatment influenced the resistance of berry skin, that was significantly higher for the NEW grape $(0.32 \pm 0.00$ $\mathrm{kg})$ than for the REF one $(0.26 \pm 0.02 \mathrm{~kg})$. This means that the former grape was likely less sensitive to mechanical damages occurring at harvest and during post-harvest.

Total skin phenol accumulation was similar or higher when compared to that found in 'Italia' grapes sampled in the same vineyard during a trial run two years prior [11]. In the present trial, grapes under the NEW cover maintained, at harvest, high values of skin TP and TF, that decreased in the grapes under the REF cover (Fig. $3 a$ and $3 b)$.
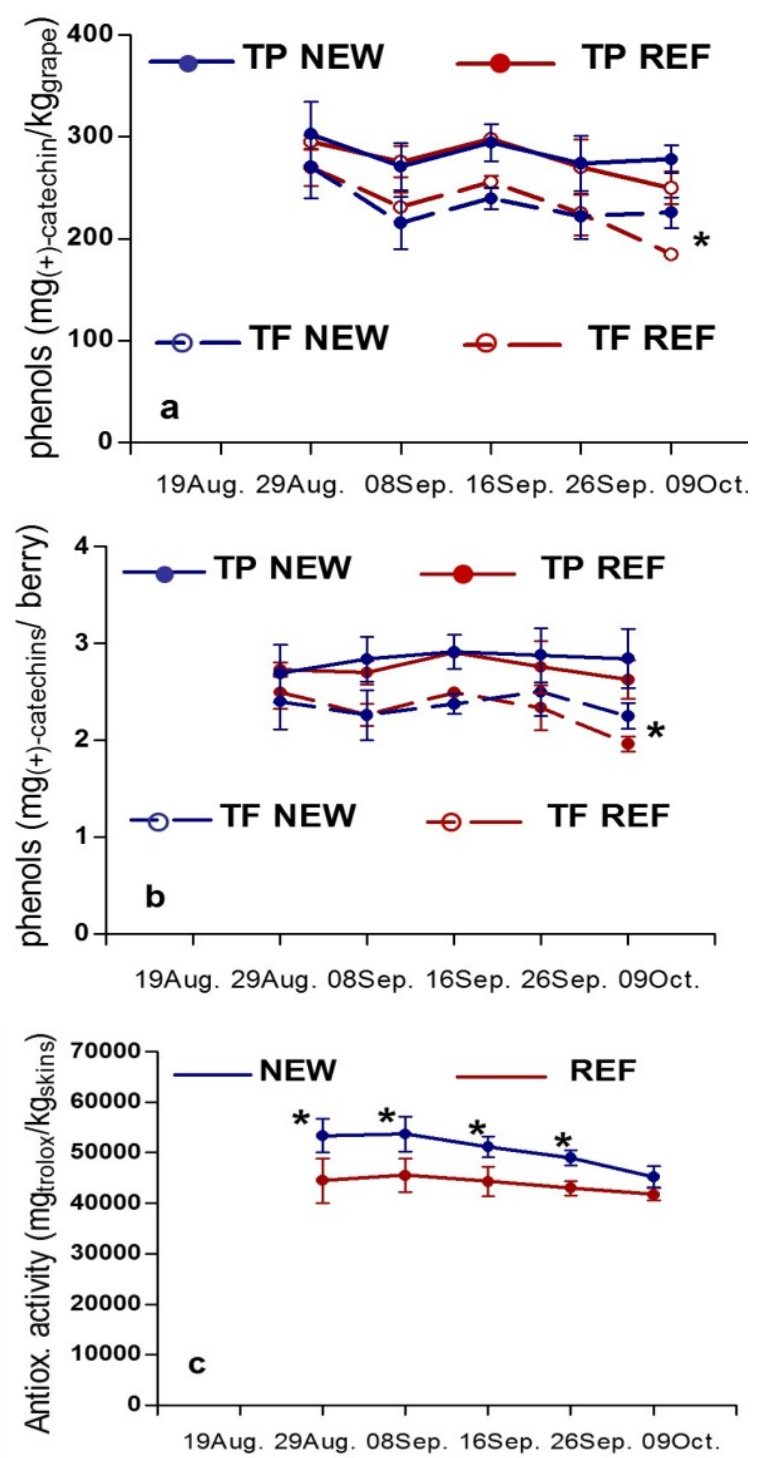

Fig. 3. Evolution indices of berry skin TP and TF content per kilogram of grapes (a) or per single berry (b), and of AA in 'late covered' grape cv. Italia, according to type of plastic cover (bars represent standard errors; * indicates sampling date where ANOVA $F$ test was significant at $p=0.05$ ). 
For $\mathrm{TF}$, this difference between treatments was significant when expressed either per kilogram of grapes $(\mathrm{NEW}=+22 \%)$, or per single berry $(\mathrm{NEW}=+15 \%)$. Accumulation of TP, and even more of TF, being processes associated to photoprotection, are diminished by a low availability of UV radiation; moreover, its final amount is negatively affected by temperatures greater than $30{ }^{\circ} \mathrm{C}[12,13]$. The NEW cover likely favored TP and TF accumulation because of its much greater transparency to UV radiation; this effect was more evident after mid-September; that is, when the last leaf thinning increased the light penetration through the canopy gaps to the ground which reflected light upwards. Skin flavonoids, together with phenolic acids, carotenoids, and anthocyanins in red cultivars, are major compounds - although not the only ones-related to grape antioxidant activity, and therefore its health benefits [14]. Antioxidant activity of grape skin extracts is known to change with cultivar, vintage and ripening level [15]. In the present trial, AA index of 'Italia' skin extracts was significantly higher in the NEW treatment at any date except harvest (Fig. 3c). Clearly, other compounds (e.g. other phenols, vitamins, etc.) were involved in this response.

At harvest, 12 volatile compounds were detected (Tab. 3). Grapes covered with the NEW sheet were particularly rich in linalool compounds, that are widely known as the most involved in the typical muscat aroma of cv. 'Italia', and in $\alpha$-terpineol, that confers sweet, floral, rose, and fruity aromas. Linalool, and the expression levels of the representative genes, may be higher in berries receiving more UV radiation [16]. Grapes covered with the REF sheet were particularly rich in hexanal (associated with green aroma), and ethanol.

Table 3. Volatile compounds detected in 'late covered' grape cv. Italia, according to the type of plastic cover.

\begin{tabular}{|c|c|c|c|}
\hline \multirow{2}{*}{ Volatile compound } & \multirow{2}{*}{$\begin{array}{c}\text { Retention } \\
\text { time }\end{array}$} & \multicolumn{2}{|c|}{$\begin{array}{c}\text { Concentration }(\mu \mathrm{g} \\
\text { internal standard } \\
\text { equivalent/100 grapes }\end{array}$} \\
\cline { 3 - 4 } & NEW & $\mathrm{REF}$ \\
\hline Acetaldehyde & 5.174 & $\begin{array}{c}0.005 \\
\pm 0.00026\end{array}$ & $\begin{array}{c}0.008 \\
\pm 0.0048\end{array}$ \\
\hline Ethyl Acetate & 8.055 & $\begin{array}{c}0.023 \\
\pm 0.0018\end{array}$ & $\begin{array}{c}0.028 \\
\pm 0.0162\end{array}$ \\
\hline Ethanol & 9.55 & $\begin{array}{c}0.146 \\
\pm 0.0080\end{array}$ & $\begin{array}{c}0.304 \\
\pm 0.1752\end{array}$ \\
\hline Hexanal & 15.168 & $\begin{array}{c}0.69 \\
\pm 0.1034\end{array}$ & $\begin{array}{c}0.970 \\
\pm 0.5610\end{array}$ \\
\hline 1-Hexanol & 27.891 & $\begin{array}{c}0.079 \\
\pm 0.0047\end{array}$ & $\begin{array}{c}0.084 \\
\pm 0.0483\end{array}$ \\
\hline 2-Hexen-1-ol, (E)- & 30.278 & $\begin{array}{c}0.028 \\
\pm 0.0031\end{array}$ & $\begin{array}{c}0.024 \\
\pm 0.0139\end{array}$ \\
\hline cis-Linalool oxide & 31.972 & $\begin{array}{c}0.029 \\
\pm 0.0032\end{array}$ & $\begin{array}{c}0.015 \\
\pm 0.0088\end{array}$ \\
\hline Acetic acid & 32.142 & $\begin{array}{c}0.008 \\
\pm 0.0006\end{array}$ & $\begin{array}{c}0.014 \\
\pm 0.0083\end{array}$ \\
\hline 1,6-Octadien-3-ol, & 36.186 & $\begin{array}{c}2.15 \\
\pm 0.2700\end{array}$ & $\begin{array}{c}1.420 \\
\pm 0.8177\end{array}$ \\
\hline 3,7-dimethyl- & 38.701 & $\begin{array}{c}0.012 \\
\pm 0.0020\end{array}$ & 0 \\
\hline $\begin{array}{c}\text { 1,5,7-Octatrien-3- } \\
\text { ol, 3,7-dimethyl- }\end{array}$ & 380 \\
\hline
\end{tabular}

\begin{tabular}{|c|c|c|c|}
\hline p-Menth-1-en-8-ol & 41.895 & $\begin{array}{c}0.076 \\
\pm 0.0060\end{array}$ & $\begin{array}{c}0.032 \\
\pm 0.0185\end{array}$ \\
\hline $\begin{array}{c}\text { 2,6-Octadien-1-ol, } \\
\text { 3,7-dimethyl- }\end{array}$ & 46.139 & $\begin{array}{c}0.033 \\
\pm 0.0166\end{array}$ & $\begin{array}{c}0.028 \\
\pm 0.0163\end{array}$ \\
\hline
\end{tabular}

\section{Conclusions}

The radiometric properties of the rain shelter proved to influence both the canopy microclimate and grape quality. Hence, those properties must not be overlooked when choosing the plastic cover for 'late covered vineyards'. A modest reduction of transmissivity to IR short radiation, with a consequent decrease in air temperature, increase of relative humidity and lowering of air VPD, had a positive effect on the final berry weight. On the other hand, a more humid microclimate likely stimulated berry rot. The high transmissivity of the new cover to UV radiation seemed responsible for main differences concerning berry phenol accumulation, antioxidant activity and some aromas. Providing a proper canopy management, UV radiation can reach bunches, also as reflected from the ground.

\section{References}

1. V. Novello, L. de Palma. Acta Hortic., 785, 353-362 (2008)

2. L. de Palma L., V. Novello. Proc. 4th Int. Symp. on Table Grape (ISSN 0717-4810), 37 (2000)

3. L. de Palma, V. Novello, L. Tarricone, G. Lopriore. Quad Vitic Enol Univ Torino, 27, 99-125 (2004)

4. M.W. Fidelibus, S.J. Vasquez, S. Kaan Kurtural. HortTechnology, 26(2), 141-147 (2016)

5. G. Vox, E. Schettini., G. Scarascia-Mugnozza, L. Tarricone, L. de Palma. Acta Hort., 1037, 897-904 (2014)

6. G. Vox, E. Schettini. Polym Test 26, 39-651 (2007)

7. R. Di Stefano, M.C. Cravero. Riv.Vit.En.,44,2 (1991)

8. R. Re, N. Pellegrini, A. Proteggente, A. Pannala, M. Yang, C. Rice-Evans. Free Radical Biology \& Medicine 9/10 (1999)

9. P. Carbonell-Bejerano, M.-P. Diago, J. MartínezAbaigar, J.M Martínez-Zapater, J. Tardáguila, E. Núñez-Olivera BMC Plant Biology, 14, 183 (2014)

10. C. Van Leeuwen, O. Tregoa, X. Choné, B. Bois, D. Pernet, J.-P. Gaudillère. J. Int. Sci. Vigne Vin, 43 (3): 121-134 (2009)

11. S. Belviso, F. Torchio, V. Novello, S. Giacosa, L de Palma, S. Río Segadea, V. Gerbi, L. Rolle. Journal of Food Composition and Analysis, 62, 14-22 (2017)

12. J. Bergqvist, N. Dokoozlian, N. Ebisuda. Am. J. Enol. Vitic. 52, 1-7 (2001)

13. K. Koyama H. Ikeda, P.R. Poudel, N. GotoYamamoto. Phytochemistry, 78, 54-64 (2012)

14. C.-I. Bunea, N. Pop, A.C. Babe, C. Matea, F. V Dulf, A. Bunea. Chemistry Central, 6:66 (2012) 
15. B. Bartolomé, V. Nuñez, M. Monagas, C. GómezCordovés. Eur Food Res Technol, 218:173-177 (2004)

16. K. Sasaki, H. Takase, S. Matsuyama, H. Kobayashi, H. Matsuo, G. Ikoma, R. Takata. Bioscience, Biotechnology, and Biochemistry, 80(12), 23762382 (2016) 